\title{
Analysis of Al-Mawardi and Ibn Rushd political thoughts in the context Pakistani political system
}

\author{
Muhammad Umar Riaz Abbasi* \\ Department of Islamic Studies, National University of Modern Languages, Islamabad, Pakistan. \\ *Corresponding Author Email: drumarabbasi101@ gmail.com
}

Received: September 12, 2021

Published: December 15, 2021

\begin{abstract}
This study was aimed to comparatively analyse the political thoughts of Al-Mawardi and Ibn Rushd, and their possible implications in the current Pakistani political system. A qualitative method was chosen to conduct the study and they were collected from secondary sources. Besides, content analysis was used to analyse the collected data. The role of politics considered a significant part of human's life, since time immemorial. In terms of epistemological meaning, politics has a deep relation with power. Different kind of ordinances and law documents was collected related to public law in one place by Al-Mawardi and Ibn Rushd. No society, community, city, or even any country did not prevail, without an effective constitution or government structure. The famous scholar Ibn Rushd highlighted the political injustice and failure of the secular political laws which claimed to provide and established justice in the Islamic society. Muslims have bottomless faith in the political teachings of Islam taught by Hazrat Muhammad Mustafa (PBUH), His companions to accomplish in their communities. AlMarwardi and Ibn Rushd School of thought, was greatly focused on the teaching of Islam in the modern world. It was recommended that there is a need for the implementation of the Islamic laws and rules in the society, to meet the laws of Islam for the prosperity of the society.
\end{abstract}

Keywords: Al-Mawardi, Ibn Rushd, Islamic system, Islamic laws, Shari'ah, political system, Muslim World, Pakistani system, Islamic community.

How to Cite: Abbasi, M. U. R. (2021). Analysis of Al-Mawardi and Ibn Rushd political thoughts in the context Pakistani political system. Journal of Humanities, Social and Management Sciences (JHSMS), 2(2), 200-212. https://doi.org/10.47264/idea.jhsms/2.2.15

Publisher's Note: IDEA PUBLISHERS (IDEA Publications Group) stands neutral regarding jurisdictional claims in the published maps and institutional affiliations.

Copyright: ( 2021 The Author(s), published by IDEA PUBLISHERS (IDEA Publications Group).

Licensing: This is an Open Access article published under the Creative Commons AttributionNonCommercial 4.0 International License (http://creativecommons.org/licenses/by-nc/4.0/) 


\section{Introduction}

The previous time frame of the Muslim rulers and sultans was very administrative and strategic in nature, making the conditions helpful and sovereign for their people. Prominent Islamic historians and scholars identify these strengths and give their worthy recommendations to the governments and responsible authorities, to implicate and make a replica of it in the country. Islam provides an intensive collaborative approach and design method for world politics and gives the idea to confront and tackle the contemporary issues facing the Muslim world (Abbasi et al., 2021). Abu Al-Hasan Al-Mawardi speculated in his book about his thoughts for the political and Islamic system that it is the sole responsibility of the caliph to make sure that Islamic Sharia in practice all the time (Essay Sauce, 2019). Modernisation campaigns contributing differently in the Islamic societies causing a perspective and thinking viewpoint change. However, the conditions right now making the scenario more complex due to not obey the Islamic rules and regulations. Allah mentioned in the Holy Quran in Surah Al-Nisa, which follows the rules of Allah and the Sunnah of Prophet Muhammad [PBUH], to get the desired outcomes in life.

"O you who believe! Obey Allah, and obey the Messenger, and those charged with authority among you. If ye differ in anything among yourselves, refer it to Allah and "His Messenger, if ye do believe in Allah and the Last Day: That is best, and most suitable for final determination" (Tanzil, n.d.).

In a similar case, famous scholar Ibn Rushd also highlighted the political injustice and failure of the secular political laws which claimed to provide and established justice in the Islamic society (El-Ehwany, n.d.). These famous scholars understood the paradigm shift of the Muslim Ummah, therefore suggested clear and concise ways to follow the rules of Islam and get the right track. Pakistani political system in comparison not much like the system that existed in the time of Caliphate periods, it is more likely seems to have a western-style and structure, which not portraying the image of true Islamic Shari'ah society. However, several measures were previously taken to implement the complete Shari'ah laws and benefits society from it, but the efforts are not continuing. Likewise, Al-Mawardi also explains in his theory about the power alignment and utilisation, which states that the supreme authority will be with the caliph in all matters (Al-Khamlichi, 2014; Karamat et al., 2019).

More challenges emerge in the past several decades causing contradiction in the current Islamic political system. Since the last several centuries the connection of Muslim intellectuals or ulema with common people and fair justice in the society has gradually decreased, resulting in the lack of Islamic awareness and fundamental Shari'ah laws. In this context, the comparison of Pakistani political society is quite unparalleled, because of the measures taken by authorities proving the argument of the contradiction and society difference with Islamic laws and fundamental Shari'ah rules (Khattak et al., 2017; Kuru, 2019). In the Holy Quran Allah states that do justice and be kind with your subordinates in Surah Al-Nisa.

"Verily, Allah commands that you should render back the trusts to those, to whom they are due; and that when you judge between men, you judge with justice. Verily, "How excellent is the teaching which He (Allah) gives you! Truly, Allah is Ever All-Hearer, All-Seer” (Surah Al-Nisa, Verses: 59-59). 
Allah says in Quran, that always believed in your God, and seek for his guidance to get the right path, Allah says in Surah Baqarah:

"This is the Book about which there is no doubt, a guidance for those conscious of Allah - Who believe in the unseen, establish prayer, and spend out of what We have provided for them, And who believe in what has been revealed to you, [O Muhammad], and what was revealed before you, and of the Hereafter they are certain [in faith]. Those are upon [right] guidance from their Lord, and it is those who are successful" (Surah Baqarah, Verses: 2-5).

In recent studies, a knowledge gap exists, indicated that the political thoughts of Al-Mawardi and Ibn Rushd are not studied completely, and the possible implications of the political thoughts have not been implemented in the Pakistani political system. Another gap identified which disclosed the need for exploration and research on the implications of the laws in current Muslim areas must be the priority. In Muslim majority areas and places, unity becomes a major hurdle in the path of structure and nation's development, and Islam gives us the lesson of strong unity and ties (Naazer, 2019). The guidance from these scholars raises some questions like, why are the current political leaders not following the Islamic rules? Is there any specific requirement for the Shari'ah laws? The significance of this research study was to cover the above-identified gaps to the superlative level. This research study also showed its significance, by outlining the historical aspects of the Islamic period with existing political Islamic society, and with factual recommendations in the Muslim Islamic society, this study showed much effectiveness by identifying and filled the gap created with the insufficient awareness of the Islamic laws.

The study is about the current political system and its comparison with the historical periods of our forefathers has an unparalleled difference. Like the Caliphate period of the first four caliphs Hazrat Abu Bakr Ibn Quhafa, Hazarat Umer Ibn Khattab, Hazrat Usman Ibn Affan, Hazrat Ali ibn Abi Talib (R. A), set examples of their life, governance, attitude, and beliefs. Some of the scholars including Abu Al-Hassan Al-Mawardi and Ibn Rushd have significantly described the periods of the Caliphate and the way of governance for after sultans and the person in power. The state was a progressing or evolving entity through the formative period of Islam (Afsaruddin, 2011). The objectives of this study are:

- To compare Al Marwadi and Ibn Rushd's school of thoughts in different aspects of the system of Muslim World.

- To assess different factors of school of thought influencing the Muslims and the current political system of Pakistan.

- To evaluate the possible implications of School of thoughts on the current Pakistani political system.

- To suggest and recommend appropriate ways to enhance the positive influence of these school of thoughts on the current political system of Pakistan.

\section{Methodology}

The research methodology section is based on the research study's topic. The portion contains the information regarding the methodologies of the research obtained in this study. Furthermore, the methodology includes the methods of data collection meanwhile the analysis 
of the data according to the research study. The research design incorporated in this research study is qualitative research. Moreover, the use of qualitative design in the research is justified considering the nature of the research. The present research was intended to use interpretivism philosophy as it is an appropriate choice for qualities research. This philosophy enabled the researcher to understand the subject through intervention and interpretation of the real subject. Another important reason to use this philosophy in this research is that it facilitates that understanding of how and why. Therefore, it helped the researcher to comprehend in what way Al-Mawardi and Ibn Rushd's political thoughts are different from each other and what implications they have on the current political system of Pakistan.

The research study used an inductive approach considering the nature of the study and depicting the overall qualitative research design. Besides, this approach is compatible with interpretivism philosophy. Therefore, the information inducted enabled the researcher to generalise the data meanwhile the approach provides the researcher further exploration in the area of comparison of Al-Mawardi and Ibn Rushd political thoughts and their implication in the current Pakistani political system. Data collection is an essential task for any research study to be performed; the data collected in this research study is performed through validated secondary sources including journals, books, scholarly articles, etc. These sources were used by the researcher to accumulate information regarding the Al-Mawardi and Ibn Rushd political thoughts. The reason to use secondary data is that it enabled the researcher to obtained historical insights on the topics. Besides, it was easy to collect and time-saving.

The data is collected through the secondary resources were analysed in the narrower aspect of the subject under study; the data can be assorted and analysed through various methods including thematic and content analysis. However, this research study used content analysis throughout the analysis of the findings of the research, meanwhile, the content analysis provides the researcher an insight and ability to analyse the data in a meaningful manner that qualitative data satisfies the objectives mentioned in the research. Moreover, it is an obtrusive means to collect, which was another important reason to use it.

Ethical considerations were also considered in this study. The researchers are based upon the values and morals which are essential to follow by the researcher to validate the study. The research paper intended to fulfil the mentioned objectives of the research, the study is not harmful to any of the participants, and meanwhile, the data implemented is confidential for the researcher however the data obtained from secondary resources are openly cited with the references to the past research and their researchers to provide the credits of their study findings and limitations. Furthermore, the research limitations are identified in this research study which can help future researchers in identifying the flaws and gaps of the research performed meanwhile the research recommends strategies and ways to enhance the positive influence of these schools of thought on the current political system of Pakistan.

\section{Analysis and discussion}

\subsection{Comparison of two schools of thoughts}

Politics has been a significant part of humans since time immemorial. In terms of epistemological meaning, politics has a deep relation with power. Islamic scholars have interpreted the word politics by implying that it mainly deals with human affairs and problems 
of life by keeping Islam as the source of guidance. Hence the term Khilafat is used, which means that those who represent Prophet Muhammad (PBUH), take care of the people under the principles of Islam. Prophet Muhammad (PBUH) in his lifetime, established an Islamic society in Medina that focused on keeping social and political order. After the time of Prophet Muhammad, new political thinkers started to formulate a theory that defined politics in a relatively new way. Among them were many who tried to preach the political philosophy of Islam in a philosophical context, Al-Mawardi was among those scholars who tried to establish a political theory based on the principles of Islam (Fauzan, 2018). According to Al-Mawardi, the basic tenet of Khilafat was to build institutions of power that can act as a replacement for Prophet Muhammad's rule while serving and protecting the nation. It has been interpreted that those who rule the population are the servants of God. Although leading people is a very difficult task that requires a lot of responsibility and courage, it is also implied that those who have been chosen to accomplish this task are indeed very lucky. Almighty Allah states in Quran, Surah Al Imran, Verse 104:

"And let none of you are calling a class of people to virtue, sent to the ma'ruf and prevent it from being evil, they're the ones who are lucky"

In the same way, it is said that the people who have been given power shall do it with the utmost respect to the system and do justice whenever possible. Almighty Allah states in Quran, Surah Al Maidah, Verse 8:

"O you who believe, you shall be the people who always uphold (the truth) for Allah, bearing witness with justice. And do not let the hatred of a people, encouraging you to do injustice. Applies just: that is next to piety. And fear Allah, verily Allah is Aware of what you do."

In addition to this, it is suggested that those who have been chosen to manage and rule people are entitled to do it professionally while handling all the work parted to them with utmost integrity and honour. Almighty Allah says in Quran Surat al-Tawbah, Verse 105.

And say, "work ye, then Allah and His messenger and the believers will see your work, and you will be returned to (Allah) Who Knows be the unseen and the real and preached unto you what has been you do."

Among the prominent Muslim scholars, Al-Mahawardi was one of the scholars who wrote the first book on governance under the Islamic jurisprudence and the book was titled Al-Ahkām As-Șultạniyyah. He was the one who collected all the ordinances related to public law in one place and this collection was regarded as one of the most important documents among the judges and lawmakers (Tojidinov, 2019). After its publication, Al-Ahkam had been regarded as one of the standard documents among the Muslim scholars who studied politics. It should be noted that this book was written to facilitate the Islamic ruler, governors, and leaders. In addition to this, Al-Mawardi worked specifically on writing manuscripts that helped the Kalifate in exercising power and helped them to rule according to the Islamic Law.

\subsection{The themes}

Furthermore, having a strong background in academics, as well as being open to novel ideas. 
Al-Mawardi often considered dialectical views in his writings, whose example can be seen in his writing about caliph (Muslim ruler), in which he discusses the need of a caliph according to reason, while also consider the viewpoint according to Islamic rule (Shariah) (Borrut, 2006). Despite this, most of his writings are heavily influenced by Shariah (divine law) which focuses on implementing the law under the guidance of Islamic law. Furthermore, he described the criteria for selecting a caliph which described the characteristics of a desirable caliph while also nudging on the side of one of the dynasties that happened to be a part of the power struggle at that time (Madelung, 1997). In addition to this, his written text may explore diverse ideas but supported the claims which supported Muslim ruler, and in some accounts, it can be observed that the claims he established seem to remove accountability from caliphs while removing legal checks from them by merely adapting to the archaic notion of absolute monarchy which supported the caliph at all cost and even to the point of neglecting shariah (divine law).

On the contrary, Ibn Rushd is considered one of the most significant Islamic philosophers at the time. He was the one who introduced Greek philosophy in the spheres of Islamic thought while arguing that religion and philosophy both can be considered and studied in parallel without having diametrical opposition to each other (Rosenthal, 1953). Ibn Rushd subjected the political views and ideas in the light of philosophy while studying the influence of democracy on Islamic political institutions. According to Ibn Rauhd, in terms of political order, the best political rule is one based on philosophical rule, and which works towards perfecting human beings. The main objective of the political philosophy of Ibn Rushd is to achieve the best political system and therefore, democracy should be studied in the same light.

Ibn Rushd is also known as Averroes was considered as a highly creative and philosophically sound individual who did not only establish new ideas into the existing traditional sphere of knowledge but also raised questions regarding ways of attaining true knowledge (AbdelMaguid \& Abdel-Halim, 2015). Ibn Rushd posited the Islamic rule of law (Shariah) in the light of philosophy and proposed that to achieve a clear understanding of the law, those subjected to formulating laws must be well versed in the method of reasoning to correctly explore and interpret the doctrines mentioned in the Law (Shariah). The extent to which Averroes explored ideas of Greek philosophy, he not only influenced his circle but also contributed to modern secular ideas adapted by Christian and Jewish philosophers and thinkers as well (Islam, 2018). This can be noted by the fact that Dante Alighieri regarded Ibn Rushd as one the most notable philosophers that he included in the First Circle of Hell in which he was accompanied by Socrates, Plato and Aristotle as well. Furthermore, he argued that even Quran itself puts emphasis on succumbing to the side of thinking and reasoning.

"Those who listen to all statements, and then follow the best of it. These are the ones whom God has guided, and these are the ones possessed of minds" (39:18 Surah)

In regard to the state of rule at the time, Averroes argues that those states without accountability and utmost authoritarian rule are tyrannical which shares the same notion contributed by Plato referring to Persian rule in his Laws. Furthermore, he disregarded tyrannical rule and posited it directly against the democratic one (Rosenthal, 1966). While studying both the philosophers, where Ibn Rushd (Averroes) considered the philosophical approach as a sound way to attain knowledge and defended falsafa (philosophy), along with advocating the view that philosophy 
and the Law (Shariah) can work in harmony with each other. To establish the best political regime, Ibn Rushd proposed that those who are given political authority should be familiarized with the teachings of philosophy, as it can help to correctly interpret and understand the Law (Shariah) - which is the main guiding source for the political system based on Islamic values. While Al-Mawardi wrote scriptures that gave a definite structure to formulate a book of laws that can facilitate the rulers at hand while considering dialectical opinions in his writings. It can be noted that Averroes himself studied Greek philosophical ideas under the lens of Islamic Shariah which considers God (Allah) as the supreme deity (Butterworth, 1992).

\subsection{Implications of possibilities in the current Pakistan political system}

No society, community, city, or country can exist without an effective and good government. However, it was deliberated by Ibn Rushd and Al-Marwardi that it is necessary to follow Islamic Sharia when living in an Islamic state. Moreover, no government can continuously live without an honest and stable framework of politics (Abbas, 2007). Ibn Rushd stated that the connection of politics and Islam is a matter of great anxiety for Muslims, as well as nonMuslims. There has been wide confusion of the term political Islam among non-believers (Rosenthal, 1953). According to Al-Marwardi, political Islam is any sort of Islamic interpretation that functions as the base for political acts and identity (Abbasi et al., 2021). More clearly, it indicates to the cliques that validates modern deployment of politics on Islamic authority, a movement that emerged in the end of $20^{\text {th }}$ century.

Muslims have a deep trust in the political teachings of Islam taught by Hazrat Muhammad (PBUH), His companions, and other Prophets, to be executed in their communities and states (Abbas, 2007; Naazer, 2018). However, Pakistan, and several Muslim empires and military governments have strolled off from the Islamic framework of regulations and rules and are prone more towards colonialism and modernism, etc. As a result, according to Ibn Rushd this causes great justice and injustice between the nation and people living in it (Shamey \& Kirchner, 2020). Moreover, modern theories are depicting a negative picture of the Islamic political system due to incidents like 9/11 (Abbasi et al., 2021).

Al-Marwardi and Ibn Rushd School of thought greatly focused on the Islamic teaching of Islam in the modern world. Al-Marwardi wanted the Muslim nations to follow the Islamic teachings and Sharia which also includes that the state or nation should be governed by Caliph. Due to which Al-Marwardi has also explained in his studies, the steps for selecting the Caliph of a Muslim nation (Ringgren, 1972). However, in Pakistan, the military and political leaders have used Islam to increase acceptability for their regulation as a policy of the state (Moaddel, 2002). Moreover, to strengthen religious party roles in society and politics, Pakistan's Objective Resolution 1949, emphasized the rising political influences of religious supporters with 2 provisions of Islam. First was a declaration of divine over general control and authority. Therefore, enabling restrictions on parliament's scope and inferring the duties as sacred belief or trust. Second, to allow Muslims to live their lives according to the requirements and teachings of Islam as mentioned in the Holy Quran and Sunnah. These rules and laws were greatly followed under the military rule of Zia Ul Haq (1977- 1988) (Bajoria, 2011). He introduced federal Sharia court, Islamic Laws, made Islamic education compulsory in educational institutes. In addition, to promoting madrassas and religious institutes, he also Islamise the army through involving the teaching of Islam in military training (Bajoria, 2011). Zia was governing a democratic state, though, his way of governing Pakistan was based on the 
teaching of Islam and Sunnah. The method was highly stressed by Ibn Rush and Al- Mawardi (Rosenthal, 1953; Katsina, n.d.).

However, after his death, the political system of Pakistan inclined towards the modern democratic system (Afzal, 2017). Moreover, Pakistan's system of politics operates under the nation-state model. The Muslim scholars have a confusing connection with Pakistan. They realise the importance of executing Sharia, however, they live in nation-states world. Shortly, the nation-state can take over Sharia law in Pakistan. Therefore, Al-Marwardi and Ibn Rushd School of thought greatly emphasised that Muslim Sharia law and state law should be dialogically interrelated with one another (Wilson Centre, 2018; Naazer, 2019).

\section{Findings and recommendations}

\subsection{Observation of the theme}

In today's world, both Muslims and non-Muslims are fascinated by the link between Islam and politics. The growth of "political Islam" has perplexed and alarmed non-Muslims. Many Muslims, for their part, have stated that Islam is the answer to the oppression and injustice they have experienced at the hands of secular nationalist dictators and self-serving monarchies that have not progressed toward democracy. Muslims have been raised on stories of the Prophet Muhammad (PBUH) and his companions' righteous reign; thus, they have a strong belief in Islam's ability to transform society. The Islamic political system, which was founded by Allah's last Prophet, Hazrat Muhammad Mustafa (S.A.W), was carried out by the four Islamic Caliphates, and was safeguarded by Imam Hussain (A.S), is a shining model for the modern Muslim world.

In the Islamic world, Ibn Rushd was a key figure in the defence of Greek philosophy against the Ash'ari theologians (Mutakallimun), led by al-Ghazali, as well as the restoration of Aristotle's teachings. While Al-Marwadi saw as a religious leader who was in charge of establishing religious responsibilities. He had to defend the religion, lead Muslims in prayer, institute Zakat fasting, and make the hajj easier. He was also a moral reformer therefore he had to be well-versed in religion (Khan, 2001).

Throughout the study, Ibn Rushd was a transitional person who slid between East and West's intertwined histories. He was well-known scholar in his day, and he benefited from the Caliphs' support in Marrakesh, where he was able to influence educational affairs and foster peace between philosophy and religion. On the other hand, one of the three interpretations are given by Al-Mawardi, all of which highlight the necessity for a unified and scientific approach to executing Islamic rulings. In the first interpretation, he emphasizes the political dimension and suggests that leadership should be handed to those who are capable of carrying it out (alMawardl, 4:58 2001).

Several significant procedural and semantic problems are addressed to reconstitute historical and middle-era notions of Islamic political philosophy in the present period. The fact that such concepts of both schools of thought are flexible in form because they are immersed in the theological doctrine of the Holy Quran presents a huge difficulty for current social researchers in understanding basic political notions of historical and middle-era Islam. As a result, they are at odds with the political ideas of Western nations. 


\subsection{Improvement in Pakistani political system considering Al-Mawardi and Ibn- Rushd school of thoughts}

"Rulers are leaders who govern and guardian of religion for its followers. Thus, if a leader does not do justice, then none of the people who uphold justice, and vice versa if it was not unjust then the public will follow him" (Al-Mawardi, 1960).

Pakistan's struggle for survival has been as captivating as it has been uncertain since its inception. Despite its large Muslim population's shared faith, Pakistan has been struggling to identify a national identity and develop a democratic framework for its linguistically varied population (Asia Society, n.d.). Pakistan is an important strategic country with one of the world's largest Muslim populations. In a bloodless coup in October 1999, Pakistan's Chief of Army Staff Gen. Pervez Musharraf deposed Prime Minister Nawaz Sharif. because of the learning concept of Ibn Rushd that country needs only fairness and not be deal in corrupt circumstances, hence it is the first sign towards improvement. Pakistan is a democratic federal country with Islam as its official religion.

Furthermore, as per the school of thoughts, now Tehreek-e-Taliban in Pakistan (TTP) has grown powerful enough to expand its influence beyond tribal regions to major cities. They are not only working in Quetta and Peshawar for some time, but they are also dispensing justice and spreading terror in Karachi, which accounts for a fourth of Pakistan's GDP. On a political level, Furthermore, in the light of School of Karachi's ease of operating is significant since it indicates that they are in the process of replacing political parties such as the Muttahida Qaumi Movement (MQM), Pakistan People's Party (PPP), and Awami National Party (ANP), therefore limiting Pakistanis' political space (Hussain, 2013). Thoughts, the issue has gotten much more complicated from the days of foreign countries sponsoring diverse factions to the usage of Islamic state organizations in India and Afghanistan. Different jihadi organizations have been intertwined not just for operational convenience, but also for the same aim of creating an Islamic Caliphate in Pakistan and elsewhere. The Quran also says that following are right and wrong:

"You are the best of the nations raised up for (the benefit of) humanity; you enjoin what is right and forbid the wrong" (Surah Al Imran, Verse: 110).

Only competent education can bring about a long-term good change in society. Even when a revolution is unavoidable, the step of adequate community education and awareness is required. As Al-Mawardi, offers answers to the constant dread of Allah that mankind face. Human subjection to God inspires communal allegiance to the government, and obedience to God motivates people to support government policies. This would not have been feasible without the existence of a strong leader who could ensure that people followed government regulations that have consequences for harmonization and integration relation with man, and his fellow man, the universe, even with God. The authority of those who have been chosen as leaders is also recognised in the Quran:

"O you who believe! Obey Allah and obey the Messenger and those in authority from among you" (Surah Al Nisa, Verse: 59). 
Furthermore, Pakistan's status as an Islamic ideology state has a long history and is strongly related to the Pakistani military's praetorian ambitions as well as the worldview of the Pakistani elite. Islam will continue to play a prominent role in Pakistani politics for the foreseeable future (Hussain, 2013). Furthermore, scholar's highlights the main functions which held in the Pakistan nowadays likely; the ruler's responsibilities, according to Al-Mawardi, include guarding the faith, executing and preserving justice, protecting life and property, establishing peace and security, defending the country, managing financial issues, and providing personal supervision over public affairs (Islahi, 2005).

Are all related to the current affairs of the Pakistani political systems as they are under the working conditions to upward improvement and enlighten the economy with further growth and advancement. Same as throughout the period, all the circumstances were in a way to make an economy accurate while, from the current situation of $21^{\text {st }}$ century these concerns are on the upward conditions but, the way the leaders corporate hence leads to the success of the school of thoughts to bring changes and make current Pakistan more appropriate with the concept of Islamisation. As the Prophet Muhammad (PBUH) stated:

"The whole humanity is created and supervised by Allah and most beloved among them is he, who is most beneficial for mankind" (Al-Tabrani n.d., Hadith No: 10033). In his last sermon, Hajj Tul-Wada (the last pilgrimage), the Prophet (PBUH) said, "O, people! Lo your Lord is One, no Arab is superior to a non-Arab and no non-Arab is superior to an Arab. No black is better than red, and no red is better than black. Then the only criterion for superiority and honour is piety" (Mehfooz, 2021).

\subsection{Recommendations}

According to the above discuss themes, Pakistan should lead to these changes as per the two schools of thought likely; Freedom of the press from foreign or internal control, economic approach that emphasizes fundamental needs for the most underprivileged, as well as growth, job creation, and equality, maintain a Shariah-compliant corporate planning, a business and financial infrastructure free of Reba. The Islamic economic system disregards corrupt manmade systems and protects honour, the rights of women, minors, and orphans, and prohibits all forms of prostitution, pornography, or any activities that exploit the charms and physical attractiveness of women, as well as alcohol, gambling, a downward spiral of corruption, social turmoil, and moral devastation. The current Islamic political problem can be overcome if we apply and execute an Islamic economic system guided by the Holy Quran in our country with a suitable check and balance plan.

\section{Conclusion}

In the mainstream, political thoughts about the Islamic society and Shari'ah laws exert strong emphasis on the practices of Islamic essential rules and regulations. Pakistani current political system however contradicting with the Islamic Shari'ah laws at several stages, needs to align with the Islamic laws on priority. The Quranic verses define the important rules of the societal challenges and issues, with prominent guidance and a comprehensive approach. Now it is up to the authorities and governments to introduce more essential structures and approaches that align completely with Islamic Shari'ah laws to get the right direction. Our, esteemed respected 
scholars Al-Mawardi \& Ibn Rushd has dominantly established their Islamic political thoughts indicating the faith and justice in the rules and obedience with the government superiors. Holy Quran explains to us the faith and guidance in the true sense, which need to implement and have to believe on it form our leaders till the common person in the country.

The basic power and superficial distribution in the society causing changes in the nature of the law constitutions, making the political system more focus and limit with the supremacy attitude. Pakistani society and cultural system contributing as well to the current environment of the Islamic political system. Indicating the perception and approach of the current generation and strategies for the coming future. More and more new elements and factors are significantly backing the modernization in the society, which causes unawareness of our own Islamic Shari'ah laws and limitations. Furthermore, the need of implicate and true implementation of the Islamic laws and rules must be the priority of authorities and government to formulate the Islamic structure to prevail positively in the country. The pitch of the divine holy book showing us the right path to follow and have a successful life in both places of life. The need for true faith and belief is a must factor in the thoughts of our Islamic scholars and several intellectuals, to execute the ultimate internal perfection with the Islamic pattern and laws. The factual and real representation of the Islamic Shari'ah laws will turn our society become ready to initiate the active implementation of the fundamental laws of Islam. Lastly, true implication and intentional contribution in the Islamic Shari'ah laws would ultimately lead to the happiness of the society and the whole country.

\section{References}

Abbasi, M. U. R., Sultana, I., Awan, T. A., Akram, M., \& Javeid, M. A. (2021). Political aspect of Islam and contemporary theory of political Islam-critical and futuristic analysis. Linguistica Antverpiensia, 2379-2393. https://www.researchgate.net/profile/Muhammad-UmarAbbasi/publication/352357658_Political_Aspect_of_Islam_and_Contemporary_The ory_of_Political_IslamCritical_and_Futuristic_Analysis/links/60c4fe58299bf1949f53fc46/PoliticalAspect-of-Islam-and-Contemporary-Theory-of-Political-Islam-Critical-andFuturistic-Analysis.pdf

Abbas, T. (2007). A theory of Islamic political radicalism in Britain: Sociology, theology and international political economy. Contemporary Islam, 1(2), 109-122. https://link.springer.com/article/10.1007/s11562-007-0012-0

Abdel-Maguid, T. E., \& Abdel-Halim, R. E. (2015). The Qur'ān and the development of rational thinking. Urology Annals, 7(2), 135-140. https://dx.doi.org/10.4103\%2F0974-7796.152926

Al-Khamlichi, A. (2014). The relationship between religion and the state: the institution of 'Commandment of the Faithful'in Morocco. Contemporary Arab Affairs, 7(1), 54-81. https://doi.org/10.1080/17550912.2013.869991

Afzal, M. (2017, August 15). Democracy in Pakistan: Elections tell us why politicians behave badly. Brookings. https://www.brookings.edu/articles/democracy-in-pakistanelections-tell-us-why-politicians-behave-badly/

Afsaruddin, A. (Ed.). (2011). Islam, the state, and political authority: Medieval issues and modern concerns. Springer. 
Asia Society. (n.d.). Pakistan: A political history. https://asiasociety.org/education/pakistanpolitical-history

Bajoria, J. (2011). Islam and politics in Pakistan. Council on Foreign Relations, 20.

Borrut, A. (2006). Medieval Islamic political thought. Abstracta Iranica. Revue bibliographique pour le domaine irano-aryen, (Volume 27). https://journals.openedition.org/abstractairanica/6181

Butterworth, C. E. (1992). The political teaching of Averroes. Arabic Sciences and Philosophy, 2(2), 187-202. https://www.cambridge.org/core/journals/arabicsciences-and-philosophy/article/abs/political-teaching-ofaverroes/1A199436A152F15D3944A6A6BA8E95C3

El-Ehwany, A. F. (n.d.). Chapter 28: Ibn Rushd. In A History of Muslim Philosophy Volume 1, Book (pp. 339-362). Pakistan Political Congress. https://www.al-islam.org/historymuslim-philosophy-volume-1-book-3/chapter-28-ibn-rushd

Essay Sauce. (2019). Essay: Political thought of Al-Mawardi. Essay Sauce.com. https://www.essaysauce.com/politics-essays/political-thought-of-al-mawardi/

Fauzan, A. (2018). Leadership character according to Imam Al-Mawardi and its relevance in Indonesia: The study of the book Of Al-Ahkam As-Sulthaniyyah. JURNAL PENELITIAN, 39-50. https://doi.org/10.28918/jupe.v15i1.1221

Hussain, N. (2013, April 11). Pakistan's Jihadi problem and the Middle East. https://www.mei.edu/publications/pakistans-jihadi-problem-and-middle-east

Islahi, A. A. (2005). Contributions of Muslim Scholars to the history of economic thought and analysis upto 15th Century. Islamic Economics Institute, King Abdulaziz University, Jeddah. https://mpra.ub.uni-muenchen.de/53462/1/MPRA_paper_53462.pdf

Karamat, S., Muzaffar, M., \& Shah, A. S. (2019). The politics of religious extremism in Pakistan: An analysis. Review of Economics and Development Studies, 5(2), 315-322. http://reads.spcrd.org/index.php/reads/article/view/109

Khan, M. Y. (2001). A political study of Al-Mawardi with special reference to the concept of legitimacy. Doctoral Dissertation, University of Leeds. https://etheses.whiterose.ac.uk/462/

Khattak, A. H., Khattak, K. U., \& Zaheer, S. H. (2017). Security Issues in Pakistan: Its Solution in the light of Seerah. Liberal Arts and Social Sciences International Journal (LASSIJ), 1(2), 34-42. https://doi.org/10.47264/idea.lassij/1.2.4

Kuru, A. T. (2019). Islam, authoritarianism, and underdevelopment: A global and historical comparison. Cambridge University. https://www.cambridge.org/core/books/abs/islam-authoritarianism-andunderdevelopment/history/0ACBDF74C70D579B3EB27BE5095D5F88

Islam, S. (2018). The Ibn Rushd syndrome: In search of rational Muslim. Available at SSRN 3211293. https://papers.ssrn.com/sol3/papers.cfm?abstract_id=3211293

Madelung, W. (1997). Politics and revelation. Māwardī and after. By Hanna Mikhail, pp. xxxii, 95. Edinburgh, Edinburgh University Press. Journal of the Royal Asiatic Society, 7(1), 121-122. https://www.cambridge.org/core/journals/journal-of-theroyal-asiatic-society/article/abs/politics-and-revelation-mward-and-after-bymikhailhanna-pp-xxxii-95-edinburgh-edinburgh-university-press-19952995/233025BBFD39A510ABE1E32AB768402E

Mehfooz, M. (2021). Religious Freedom in Pakistan: A Case Study of Religious Minorities. Religions, 12(1), 51. https://doi.org/10.3390/rel12010051 
Moaddel, M. (2002). The study of Islamic culture and politics: An overview and assessment. Annual Review of Sociology,28(1), 359-386. https://www.annualreviews.org/doi/abs/10.1146/annurev.soc.28.110601.140928

Naazer, M. A. (2018). Islamic universalism and the nation state. Liberal Arts and Social Sciences International Journal (LASSIJ), 29), 29-41. https://doi.org/10.47264/idea.lassij/2.2.4

Naazer, M. A. (2019). Nationalism in the Muslim world: A curse or blessing? Liberal Arts and Social Sciences International Journal (LASSIJ), 3(1), 30-42. https://doi.org/10.47264/idea.lassij/3.1.4

Ringgren, H. (1972). On the Islamic theory of the state. Scripta Instituti Donneriani Aboensis, 6, 103-108. https://journal.fi/scripta/article/view/67072

Rosenthal, E. I. J. (1966). Averroes' commentary on Plato's Republic.

Rosenthal, E. I. J. (1953). The place of politics in the philosophy of Ibn Rushd. Bulletin of the School of Oriental and African Studies, 15(2), 246-278. https://www.cambridge.org/core/journals/bulletin-of-the-school-of-oriental-andafrican-studies/article/abs/place-of-politics-in-the-philosophy-of-ibnrushd/48DDB3F00D5830867F881649F4EF3C97

Shamey, R., \& Kirchner, E. (2020). Ibn Rushd (Averroes) 1126-1198. In Pioneers of Colour Science (pp. 45-48). Springer, Cham. https://link.springer.com/chapter/10.1007/9783-319-30811-1_10

Tanzil. (n.d.). Quran Navigator القرآن الكريم. Tanzil.net.

Tojidinov, F. (2019). The concept of government in the early works of Abu Hasan AlMawardi. Islam in the Modern World, 15(2), 89-104. https://doi.org/10.22311/20741529-2019-15-2-89-104

Surah An-Nisa: Ayah 58-59. Justice, Leadership, and Obedience. Musings of a Muslim. https://ouwbmmsa.wordpress.com/2015/06/22/surah-an-nisa-ayah-58-59/

Surah Baqarah: Ayah 2-5. https://khuluq.org/? $\mathrm{p}=54$

Wilson Centre. (2018, October 26). Islamic law, the nation state, and the case of Pakistan. https://www.wilsoncenter.org/event/islamic-law-the-nation-state-and-the-casepakistan 